Article

\title{
Interaction of Ulocladium atrum, a Potential Biological Control Agent, with Botrytis cinerea and Grapevine Plantlets
}

\author{
Sébastien Ronseaux, Christophe Clément and Essaid Ait Barka * \\ Laboratoire de Stress, Défenses et Reproduction des Plantes, UPRES EA 2069, \\ Université de Reims Champagne-Ardenne, UFR Sciences, URVVC, B.P. 1039, \\ Reims Cedex 2 51687, France; E-Mails: sebastien.ronseaux@gmail.com (S.R.); \\ christophe.clement@univ-reims.fr (C.C.)
}

* Author to whom correspondence should be addressed; E-Mail: ea.barka@univ-reims.fr; Tel.: +33-3-26913441; Fax: +33-3-26913427.

Received: 25 June 2013; in revised form: 7 September 2013 / Accepted: 23 September 2013 / Published: 30 September 2013

\begin{abstract}
The effectiveness of biological control agent, Ulocladium atrum (isolates U13 and U16) in protecting Vitis vinifera L. cv. Chardonnay against gray mold disease caused by Botrytis cinerea, and simulation of the foliar defense responses was investigated. A degraded mycelium structure during cultural assay on potato dextrose agar revealed that $U$. atrum isolates U13 and U16 were both antagonistic to $B$. cinerea, mainly when isolates were inoculated two days before Botrytis. Under in vitro conditions, foliar application of $U$. atrum protected grapevine leaves against gray mold disease. An increase in chitinase activity was induced by the presence of $U$. atrum isolates indicating that the biological control agents triggered plant defense mechanisms. Moreover, U13 has the potential to colonize the grapevine plantlets and to improve their growth. The ability of $U$. atrum isolates to exhibit an antagonistic effect against $B$. cinerea in addition to their aptitude to induce plant resistance and to promote grapevine growth may explain a part of their biological activity. Hence, this study suggests that $U$. atrum provides a suitable biocontrol agent against gray mold in grapevines.
\end{abstract}

Keywords: biocontrol; Botrytis cinerea; chitinase; plant defense; Ulocladium atrum; Vitis vinifera $\mathrm{L}$. 


\section{Introduction}

Gray mold disease caused by Botrytis cinerea is probably one of the most common and widely distributed diseases of vegetables, ornamentals, fruits, and even field crops throughout the world. The control of gray mold like other fungal plant diseases is mainly based on fungicides, which have been a major factor contributing to the enhanced crop yields and quality attained in modern agriculture. Nevertheless, they contribute to the problem of environmental deterioration, which in turn has a marked influence on the economy, health, and quality of life. Indeed, widespread use of fungicides has certainly decreased the incidence of fungal diseases, but has contributed also to the appearance of fungicide-resistant strains of the pathogens [1]. In addition, consumers are also becoming increasingly concerned about pesticide use and residues on food products [2]. Consequently, due to public concern for environmental safety, there is an increasing demand to develop alternative methods for disease control.

Therefore, as an alternative to fungicide control and due to the lack of resistant varieties in most crops, in the past decade, interest in biological control of plant pathogens by introducing antagonistic microorganisms onto plant surfaces, into growing media, or onto propagative material has further increased [3].

Fungi used or considered for use for biological control of pest insects and plant diseases belong to different genera, including Beauveria, Paecilomyces, Trichoderma, Ulocladium and Verticillium. However, commercial applications of these antagonists have been limited so far. Fungi positioned in the genus Ulocladium are soil saprophytes and some species, including U. atrum and U. oudemansii, have potential for use in biocontrol against foliar diseases, such as those caused by the plant pathogenic genera Sclerotina and Botrytis [4,5]. For instance, U. oudemansii (isolate HRU3) was successfully commercialized and is the active ingredient in BOTRY-Zen ${ }^{\circledR}$, a BCA product that is approved for early-season Botrytis suppression in organic and conventional viticulture in New Zealand [6]. The efficiency of $U$. atrum to control Botrytis spp. has been tested in several other crops such as tomato, grapevine and lily, and against several other pathogens in various crops. In grapevine, studies on biocontrol of gray mold were carried out by Schoene et al. [7] in 1997 and 1998 with two German white grape varieties. $U$. atrum was able to colonize necrotic grapevine tissues. Furthermore, the antagonist colonized the surfaces of inflorescences and berries of grapevine and entered ecological niches of $B$. cinerea. In addition, conidia of $U$. atrum were able to survive on the surface of grapevine bark, leaves, inflorescences and berries. Similarly, Roudet and Dubos [8] reported that $U$. atrum affects hibernating sclerotia and sub-epidermal mycelium of $B$. cinerea on shoots of grapevine in the Bordeaux region. Therefore, $U$. atrum was capable of reducing sporulation of $B$. cinerea, which may initiate primary infections, and consecutively the antagonist affected the epidemic development of gray mold in vineyards.

This study aims to determine whether $U$. atrum (U13 or U16) isolates may be used to manage the disease on grapevine. In that context, our objectives were (i) to demonstrate that U. atrum (U13 and U16) isolates displayed an ability to control the gray mold disease of grapevine leaves when infected with B. cinerea; (ii) to delineate the mechanisms potentially associated with resistance to pathogen during grapevine-Ulocladium interaction in presence of $B$. cinerea; and (iii) to analyse the effect of $U$. atrum on the growth of Vitis vinifera L. plantlets was observed. 


\section{Results}

\subsection{In Vitro Dual Cultures}

In single cultures, pathogen grew rapidly and covered the entire agar surface of Petri dishes after five days of incubation (Figure 1a). When B. cinerea was grown with $U$. atrum isolates on the same PDA plate, a significant zone of inhibition was observed around the isolates of $U$. atrum (Figure $1 \mathrm{~b}, \mathrm{c}$ ). This inhibition was more pronounced when antagonist was introduced two days before $B$. cinerea (Figure 1d,e).

Figure 1. Antagonistic interaction between antagonists (U. atrum U13 or U16) and B. cinerea. The pathogen was deposited simultaneously $(\mathbf{b}, \mathbf{c})$ or two days after $U$. atrum $(\mathbf{d}, \mathbf{e})$; The dual culture was incubated for three days at $20^{\circ} \mathrm{C}$. Note the inhibition zone between the two colonies (arrow); The test was repeated twice each with 10 replicates; a: control; b,d: B. cinerea vs. U. atrum U13; c,e: B. cinerea vs. U. atrum U16. B. cinerea $(\mathrm{Bc})$; U. atrum U16 (U16); U. atrum U13 (U13).
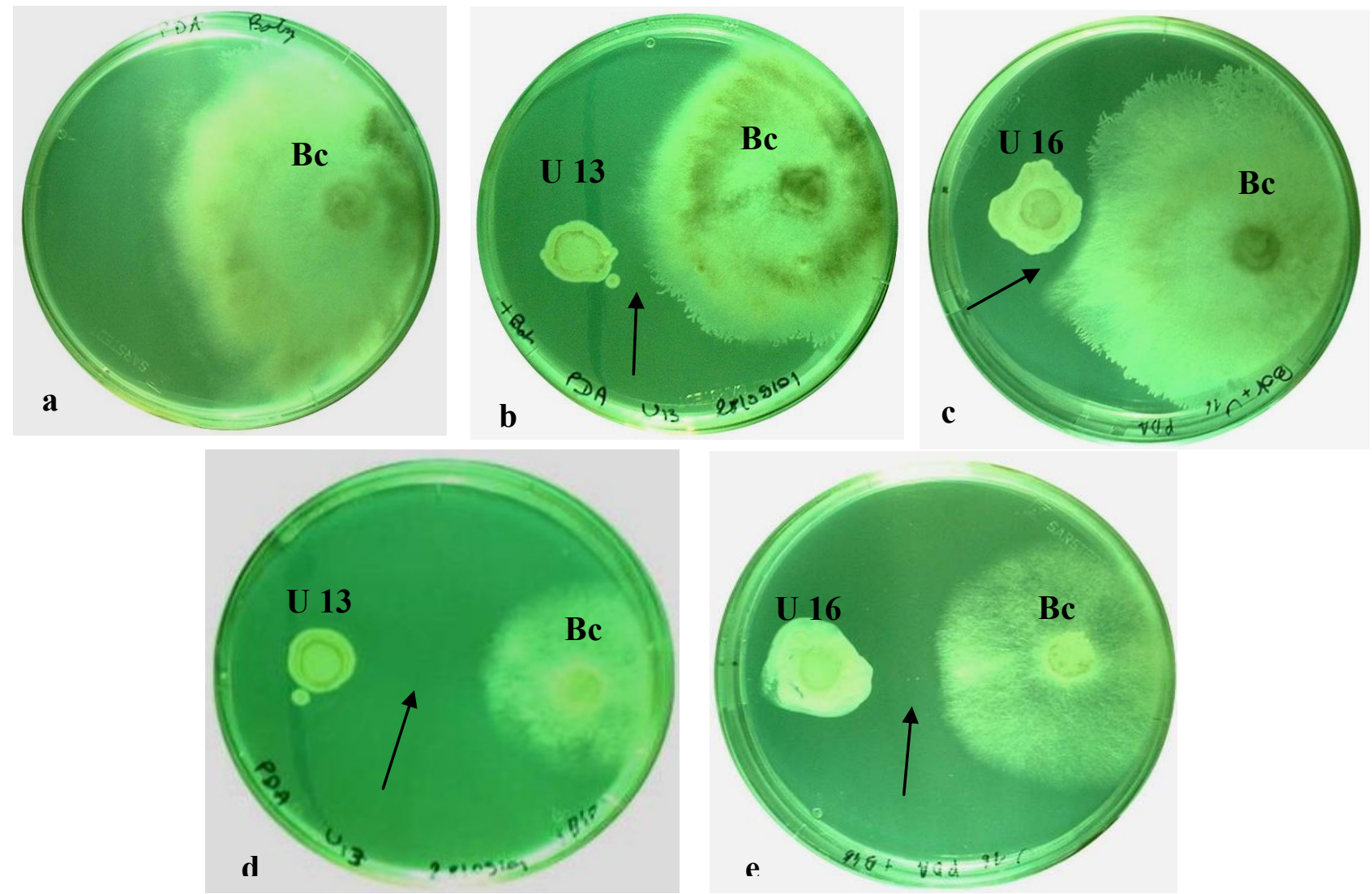

The cytoplasm of non-treated $B$. cinerea was usually densely packed with organelles, including small, membrane-bound vacuoles (Figure 2a). However, $B$. cinerea sampled from the area of interaction with $U$. atrum showed a large vesicles in the mycelium (Figure 2b). In other cases, cells of the pathogen presented a coagulated cytoplasm, while others showed an empty mycelium devoid from cytoplasm (Figure 2c,d). The absence of sporulation may be due to an indirect effect as the antagonist may affects the mycelial growth of the Botrytis so strongly that there is not sufficient biological vigor to support sporulation. Similarly, Roudet and Dubois [8] report the efficiency of U. atrum to reduce sporulation of 
B. cinerea in grapevine, which may initiate primary infections, and consecutively the antagonist affected the epidemic development of gray mold.

Figure 2. Cytological effects of $U$. atrum on $B$. cinerea. (a-c): Control mycelium; The cytoplasm of non-treated $B$. cinerea is usually densely packed with organelles (a); In some cases; (b-d): Mycelium sampled from the zone of interaction between $B$. cinerea and $U$. atrum showed the presence of large vesicles appeared in cells of the mycelium (b); In other cases, $B$. cinerea mycelium showed coagulated cytoplasm (c), or an empty mycelium devoid of cytoplasm $(\mathbf{d})$.

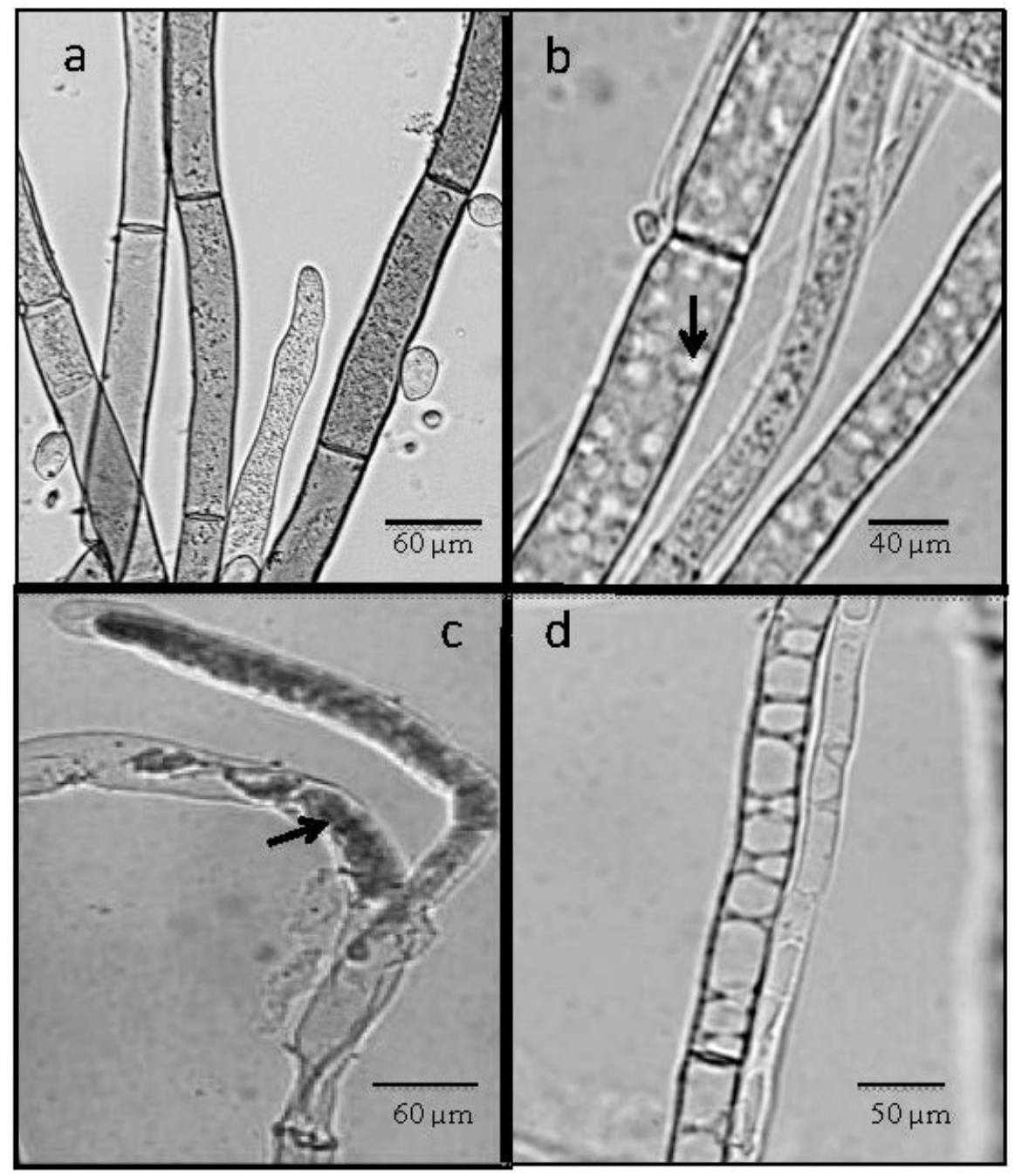

The observed antagonistic effect of both isolates of $U$. atrum toward $B$. cinerea growth confirmed results reported by Köhl et al. [9] using another isolate of $U$. atrum. A possible explanation for this behavior might be, at least for $U$. atrum U16, that the antagonist secreted a diffusible compound in the agar, which halted the growth of $B$. cinerea mycelia. However, to be more efficient, $U$. atrum should be applied two days before $B$. cinerea. Probably, when fungus was co-cultured simultaneously with the antagonists, the released substances may not have sufficient time to be secreted or may be liberated but at low amounts and consequently the inhibition zone is smaller.

Suppression of sporulation can be a valid strategy for biological control of polycyclic diseases such as those caused by Botrytis spp. [10]. Sporulation of B. cinerea was consistently reduced in the presence of 
U. atrum. This is in agreement with Köhl et al. $[10,11]$ who demonstrated very effective suppression of sporulation of B. aclada in dead onion tissue in bioassays and in onion plants. Also, Yohalem et al. [4] have reported that, while $U$. atrum 302 efficiently inhibits sporulation of B. aclada on moribund leaf tips, latent infection or adjacent tissues was not prevented. Also, Szandala and Backhouse [12] found that antagonists such as Trichoderma harzanium reduce sporulation of $B$. cinerea in bean leaf assays when antagonists were applied $120 \mathrm{~h}$ after infection by the pathogen.

\subsection{Plant Resistance}

Leaves of $V$. vinifera $\mathrm{L}$. were susceptible to fungal attack, producing the common symptoms of gray mold covering $35 \%$ of leaves surface three days after inoculation with $B$. cinerea (Figure 3 ). In contrast, when leaves were inoculated with $\mathrm{U} 13$ or $\mathrm{U} 16$ isolates of $U$. atrum then challenged with $B$. cinerea, they remained healthy without exhibiting any necrosis at their surface in response to the pathogen attacks, confirming thus the previous results occurred in dual confrontation (Figure 1). In accordance with our results, the effect of a time interval between inoculation of $U$. atrum and $B$. cinerea, respectively, was essential for leaves colonization. Pre-inoculation of $U$. atrum for more than one day led to a reduction of the pathogen's spore production by more than $70 \%$, compared to the inoculation of $B$. cinerea alone. Spore production of the pathogen was reduced by more than $90 \%$, when the antagonist became well established on the leaves four days before application of B. cinerea. However, Schoene et al. [7] demonstrated that under moderate disease pressure $U$. atrum had the potential to control gray mold, whereas under high disease pressure the efficacy was not sufficient to substitute the use of fungicides completely. Kessel [13] reported similar results in multi-side inoculation tests in ornamentals. In addition, $U$. atrum showed no antagonistic effect against Uncinula necator, neither during the growing season nor on pathogens hibernation and its outbreak in the following season.

\subsection{Electrolytes Leakage Analysis}

Ion leakage gives an indication that the plasma membrane integrity of plant cells is affected by stresses. Therefore, electrolytes leakage from leaves tissue of inoculated plants was assayed to quantify the extent of disease damage. In our experiment, no clear distinction could be made between electrolytes leakage in control leaves and the ones treated solely with the antagonists (Table 1). The low conductivity of leaves inoculated with the $U$. atrum confirmed the non-pathogenic effect of these isolates. However, the specific conductivity increased drastically for plants inoculated with $B$. cinerea, suggesting that the pathogen induced irreversible membrane damages. In contrast, when $B$. cinerea was introduced in the presence of antagonists, electrolytes leakage was higher than in control, but significantly $(p<0.05)$ lower comparatively to leaves infected solely with $B$. cinerea, supporting the visual viability test (Figure 3 ). This result suggested that $U$. atrum isolates did not affect significantly the electrolytes leakage even in the presence of $B$. cinerea. Probably, Ulocladium inactivate the toxins that may be secreted by Botrytis. Similar observation were reported by Sriram et al. [14] who indicate that isolates of Trichoderma viride inactivate a toxin produced by the rice sheath blight pathogen, Rhizoctonia solani, leading to reduction of electrolytes leakage from rice cells. 
Figure 3. Phytopathogenicity tests three days post inoculation. Leaves of Vitis vinifera L. responding to challenge with gray mold by developing large lesions clearly delimited from the surrounding healthy tissues and which are typical symptoms of gray mold (d); Leaves of grapevine inoculated with U. atrum (U13 or U16 isolates) were healthy (b,e); No gray mold symptoms were observed when $U$. atrum-inoculated leaves were challenged with $B$. cinerea $(\mathbf{c}, \mathbf{f}) ;$ a: control.

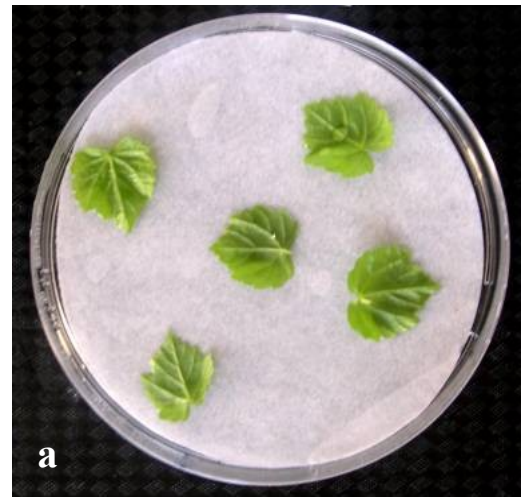

Control

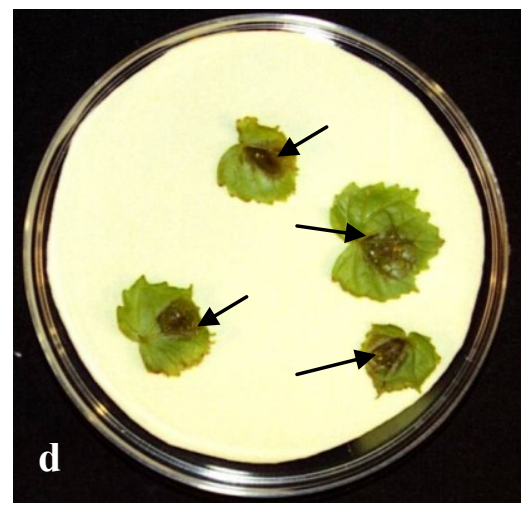

Botrytis cinerea

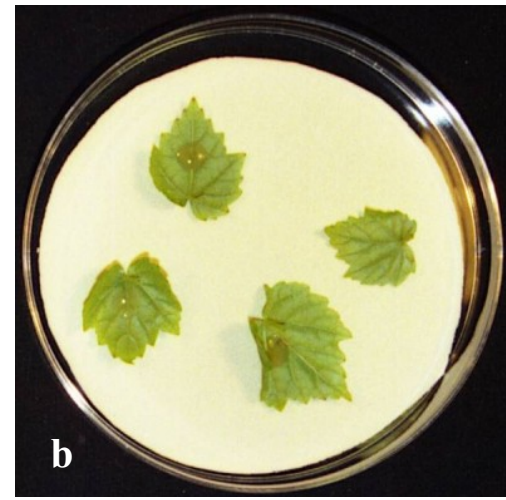

U16

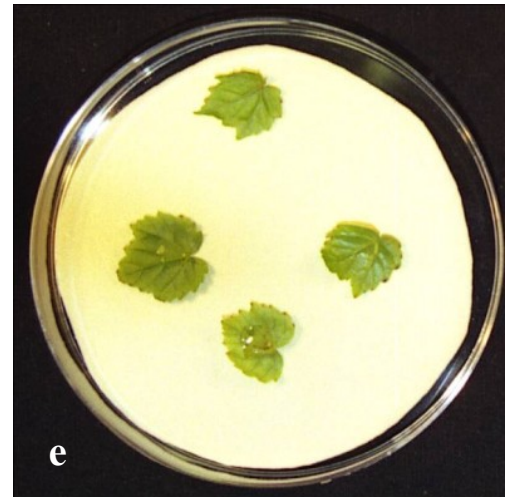

U13

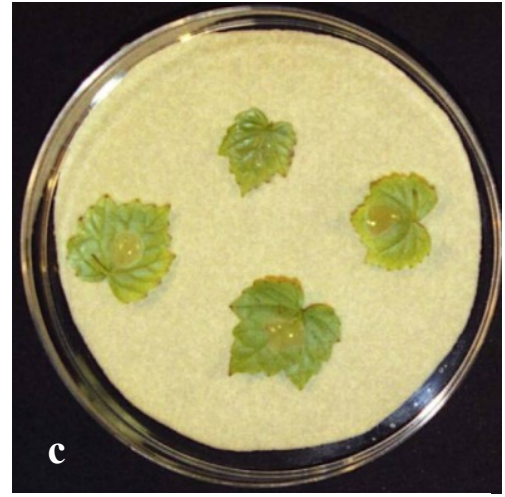

$\mathrm{U} 16+\mathrm{Bc}$

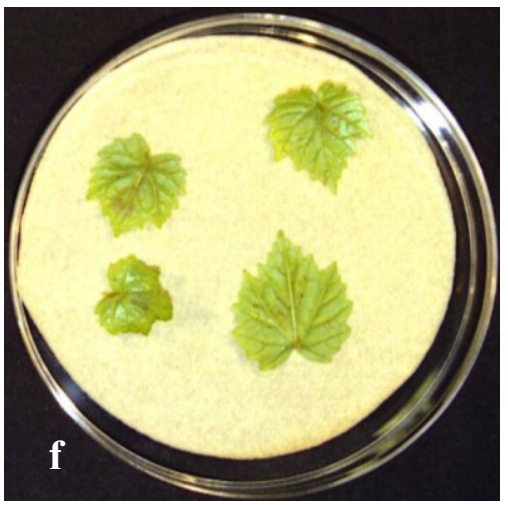

$\mathrm{U} 13+\mathrm{Bc}$

Table 1. Percent of electrolyte leakage 4 days post inoculation of grapevine ( $V$. vinifera $\mathrm{L}$.) leaves. Leaves were challenged with $B$. cinerea 3 days after being inoculated with $U$. Atrum isolates.

\begin{tabular}{cc}
\hline & Electrolyte leakage (\%) \\
\hline Control & $11.0 \mathrm{a}$ \\
B. cinerea & $67.0 \mathrm{~b}$ \\
U. atrum $\mathrm{U} 13$ & $13.0 \mathrm{c}$ \\
U. atrum $\mathrm{U} 16$ & $14.5 \mathrm{c}$ \\
U. atrum $\mathrm{U} 13+$ B. cinerea & $16.7 \mathrm{c}$ \\
U. atrum $\mathrm{U} 16+$ B. cinerea & $17.0 \mathrm{c}$ \\
\hline
\end{tabular}

Data are means of three replicates. Twenty-four leaves were used per replicate; Means within column followed by the same letter are not significantly different at the $5 \%$ level as determined by Fisher's protected LSD test. 


\subsection{Light Microscope Analysis}

In contrast to the control (Figure 4a,b), leaves tissues were intensively colonized by $B$. cinerea throughout the parenchyma (Figure $4 \mathrm{c}, \mathrm{d}$ ), confirming the pattern of fungal infection reported previously $[9,15]$. Pathogen ingress toward the inner tissues coincided with extensive plant cell disorganization such as host cell wall alteration (Figure 4c). In massively invaded areas cell walls were no longer discernible in extreme cases. Host reactions such as wall apposition or intercellular plugging were not detected (Figure 4d). Examination of leaves pre-treated with $U$. atrum before being inoculated with $B$. cinerea showed that pathogen was not able to grow at the leaves surface (Figure $4 \mathrm{e}, \mathrm{f}$ ), confirming the visual observations and, explaining also why the membrane integrity was not affected by the $B$. cinerea when on the leaves previously treated by $U$. atrum isolates as shown in the electrolytes leakage's experiment.

\subsection{Chitinase Activity}

A plant may respond to pathogen invasion by deploying several inducible defenses that slow disease spread $[12,16]$. Some of these defenses may involve production of pathogenesis-related proteins. Among PR proteins, chitinase and glucanase with potential antifungal activity are induced in plants upon pathogen attack and are associated with necrotic reactions [17]. The activity of chitinase may also contribute indirectly to induce resistance through the release of non-specific elicitors [18]. Once plants resistance has been induced, they can be considered to be in a state of "enhanced defensive capacity" [17] and are positioned to resist to subsequent infections. When compared to control, the presence of $B$. cinerea stimulated the chitinase activity in the leaves (Figure 5), supporting results of Derckel et al. [19] in B. cinerea-infected grapevine leaves. In addition, Bézier et al. [20] have reported that transcripts encoding for chitinase were identified in grapevine leaves infected by $B$. cinerea. The same activation was observed in leaves treated with U13 or U16, with an increase of 7 fold and 7.5 fold respectively compared to control. The same pattern was reported when leaves were treated with B. cinerea in the presence of $U$. atrum U13. Nevertheless, the activity of chitinase was primed in the leaves inoculated by $U$. atrum then infected with $B$. cinerea. Our results are in accordance with literature, which reports that chitinase increase in response to fungal pathogens, bacteria viruses, biotic and abiotic elicitors [21]. It is interesting to indicate that the enhanced level of chitinase activity comes directly from the host and not from Ulocladium, since no chitinase activity has been produced with the isolates used in this study (data not shown). The ability of $U$. atrum to increase the chitinase activity, in addition to its known capacity to out-compete pathogen for nutrients and space, may be the basis of the observed biocontrol activity. Nevertheless, only a slight correlation was observed between induced resistance to cucumber anthracnose and the activity of chitinase [22]. Castoria et al. [23] reported that cell wall-degrading enzymes are involved in the response of grapevine leaves or other plants to the incidence of plant pathogens, especially B. cinerea [24]. Berto et al. [25] suggested that these enzymes might play a complementary role in antagonism of $U$. atrum against $B$. cinerea. 
Figure 4. Light micrographs of samples from grapevine leaves. (a,b): non-treated leaves with healthy tissues. (c,d): leaves inoculated with $B$. cinerea. Fungal growth occured intra- and inter-cellularly (arrows), inducing a complete cell and tissues disorganization. $(\mathbf{e}, \mathbf{f})$ : leaves of grapevine previously treated with a suspension of $U$. atrum isolates, U13 (e) or U16 (f) before being treated with $B$. cinerea. The pathogen growth fails and was stopped by the antagonists. Bc: B. cinerea; le: lower epidermis; lp: lacunous parenchyma; pp: palisadic parenchyma; st: stomata; ue: upper epidermis; vb: vascular bundle. Magnification for panels a, e, and $\mathbf{f}, \times 20$; magnification for panels $\mathbf{b}$, $\mathbf{c}$, and $\mathbf{f}, \times 40$.
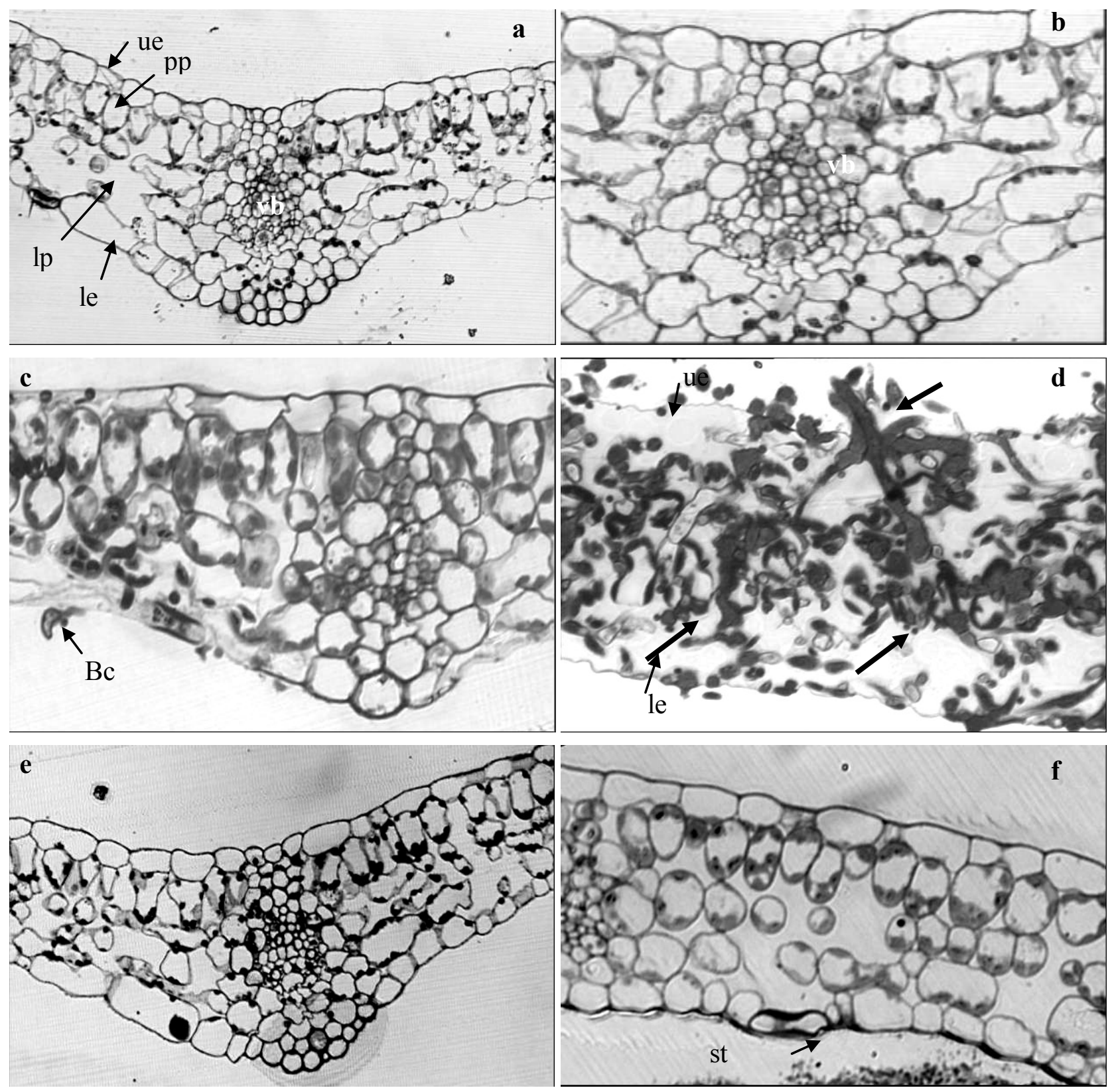
Figure 5. The effect of the presence of antagonist on the induction of chitinase activity in the shoot leaves of grapevine plantlets. Three days before inoculation with the pathogen the leaves were treated with isolate of U13 or U16 or water. The results are expressed as the mean of two separate experiments (in each experiment three different extractions were pooled). Bars with the same letters represent values that are not significantly different according to Fisher's protected LSD test $(p<0.05)$.

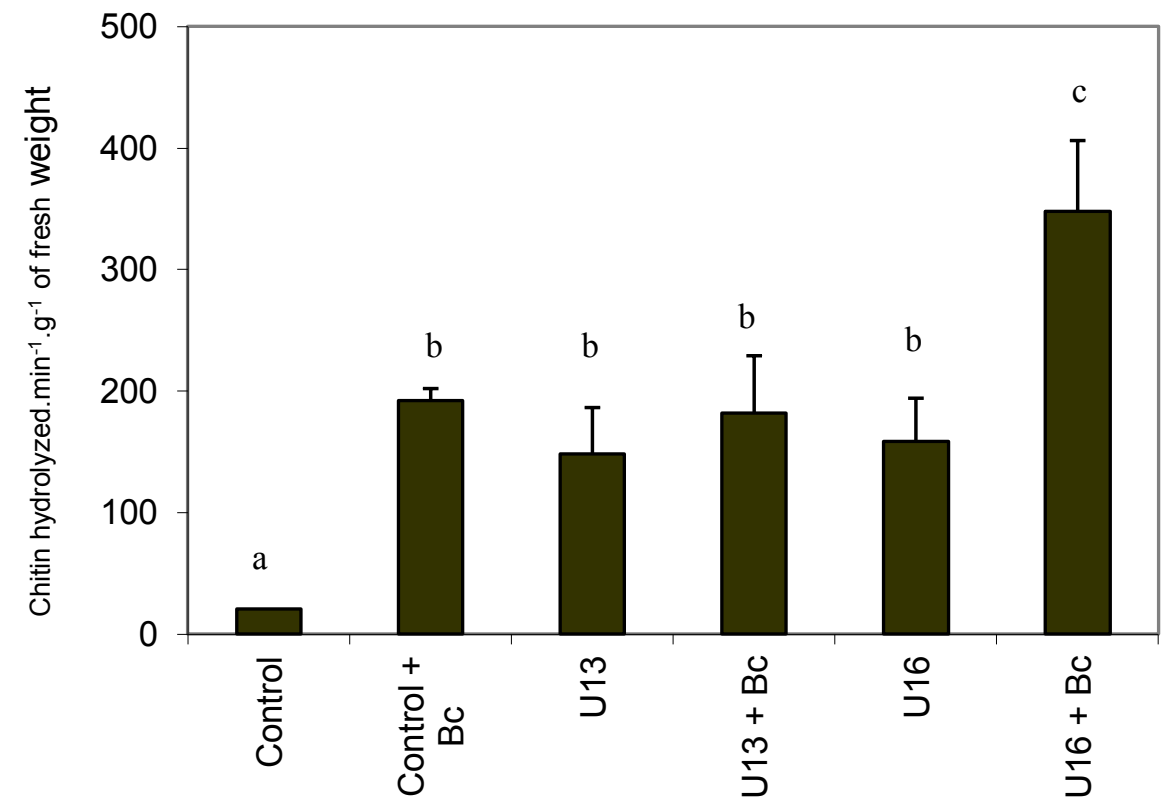

\subsection{In Vitro Colonization with U. atrum}

Grapevine plantlets co-cultured with $U$. atrum isolate U13 grew faster and had significantly more secondary roots and root hairs and leaves (Figure 6). This behavior was not observed in the presence of $U$. atrum U16. In addition, U13 induced an enhancement of the fresh weight of shoot and roots (data not shown). The stems of U13-treated plantlets were sturdier, with more lignin and phenols deposits as indicated by their red color. This is not surprising since it is well established that phenolic compound accumulations are associated with a plant defense mechanism [3]. Much like the situation with plant growth-promoting rhizobacteria, plant growth-promoting fungi (PGPF) are a class of non-pathogenic soil-borne filamentous fungi that have beneficial effects on plants [26]. Several PGPF have been reported thus far, such as species belonging to the genera Trichoderma, Fusarium, Penicillium, and Phoma [26,27]. Studies of PGPF have concentrated on the mechanisms stimulating plant growth. PGPF have been reported to produce substances such as plant hormones [28], to allow plants to utilize decomposing organic matter through mineral solubilization [29], and to suppress plant pathogens in the rhizosphere by antagonistic mechanisms, such as aggressive mycoparasitism, competition for saprophytic colonization, and the induction of plant systemic resistance [29,30]. Furthermore, they inhibit or degrade pectinases and other enzymes that are essential for plant-pathogenic fungi, such as Botrytis cinerea, to penetrate leaves surfaces [29]. To confirm the presence of the fungal antagonist inside the leaves tissues, disk of leaves from the control and U13-inoculated plantlets were deposited on solid PDA medium. Three days later, growth of U. atrum (U13) was observed around leaves tissues 
(data not shown), indicating that the isolate had colonized the whole plantlets. As endophyte, the U13 has the advantages of escaping microbial competition and of influencing the host's response to pathogen attack. Colonization of the roots is considered one of the most important characteristics of PGPF, and helps them to interact with plants to enhance growth and protection. As far as we know, this is the first time that $U$. atrum behaves as PGPF in grapevine.

Figure 6. In vitro responses of grapevine plantlets co-cultured with $U$. atrum isolate U13. The presence of antagonist induces a strong development of roots (arrows).
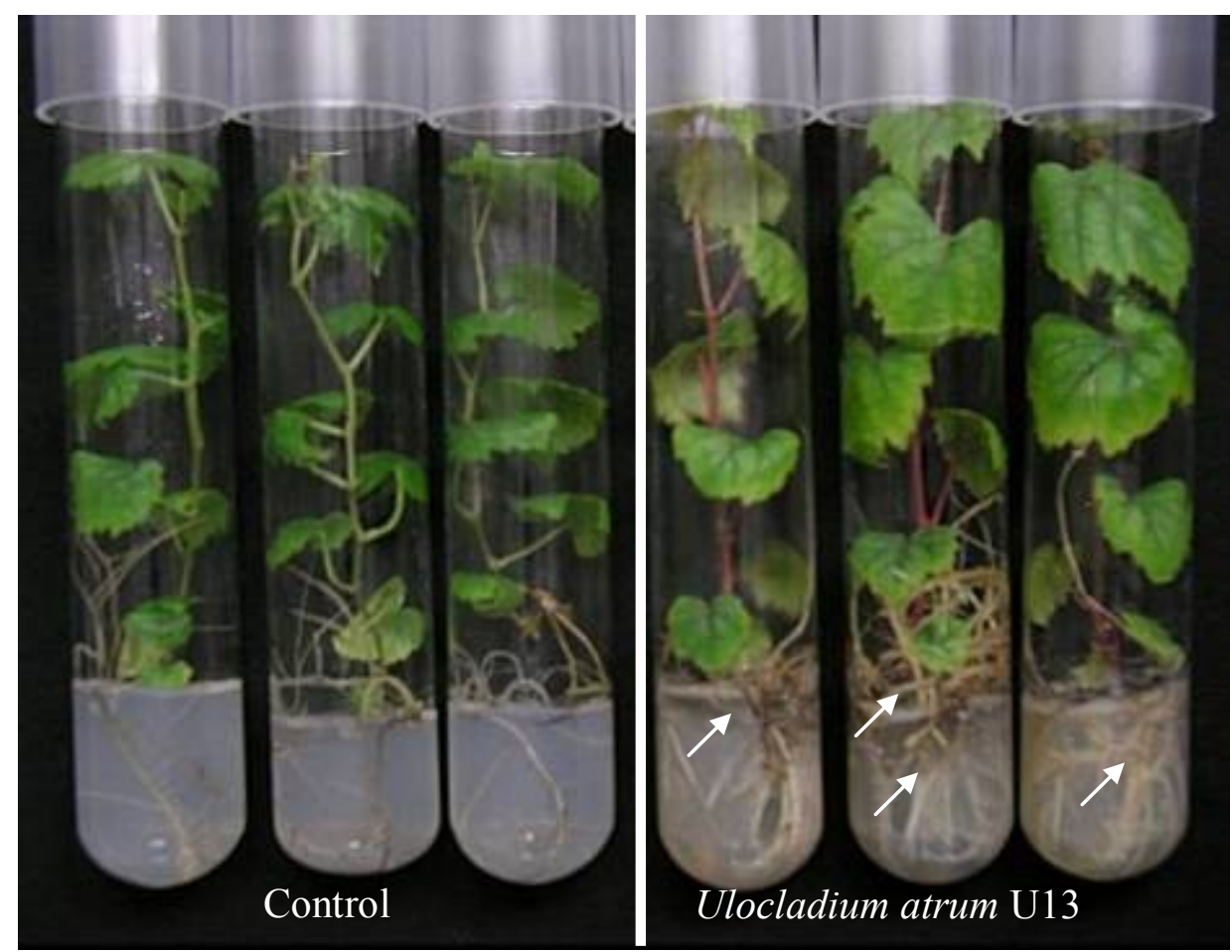

Endophytes infection may enhance disease suppression whether the mechanism involves local induction of host resistance or direct interaction with the pathogen [31,32]. In accordance with our results, Raghavendra and Newcombe [33] have reported that U. atrum colonize leaves of Populus, concluding that as endophytes, $U$. atrum may contribute significantly to quantitative resistance to Melampsora in leaves of Populus.

\section{Experimental Section}

\subsection{Ulocladium atrum Isolates}

Isolates of $U$. atrum were originally recovered from the phyllo/fructoplane of grapevines from three sites in the south Island (NZ) and provided by Dr. Stewart (Lincoln University, Canterbury, New Zealand). The biocontrol agents, U. atrum U13 and U. atrum U16 were maintained on potato dextrose agar (PDA) (Difco Laboratories, Detroit, MI, USA). Cultures of microorganisms were established by transferring an agar plug containing mycelia of each isolate on PDA in Petri dishes (90 $\mathrm{mm}$ diameter). Cultures were then incubated at room temperature. Spores were harvested by adding $5 \mathrm{~mL}$ 0.01\% (v/v) Tween 20 (Sigma Chemical Company, St. Louis, MO, USA) solutions to the agar 
plates. Spore suspensions were filtered through a sterile $25 \mu \mathrm{m}$ filter, and concentrations were adjusted to $1 \times 10^{6}$ spores $\mathrm{mL}^{-1}$, with a hemocytometer.

\subsection{Botrytis Cinerea Culture}

B. cinerea strain 630 provided by Dr. Brygoo (INRA, Paris, France) had been maintained on a potato dextrose agar. Botrytis cinerea culture was initiated by transferring pieces of solid agar medium containing mycelium to fresh solid. After 3 weeks of incubation at $28{ }^{\circ} \mathrm{C}$, conidia collected from colonies on PDA medium in the presence of sterile distilled water were filtered through a sterile $25 \mu \mathrm{m}$ filter. The density of the conidiospores of $B$. cinerea was then determined and adjusted to $10^{5}$ spores $\mathrm{mL}^{-1}$.

\subsection{In Vitro Dual Cultures}

Antagonism between $B$. cinerea and $U$. atrum was studied by placing both organisms on the same PDA plate. $U$. atrum was inoculated on PDA, $1 \mathrm{~cm}$ from the wall of each Petri dish. After incubation at $20{ }^{\circ} \mathrm{C}$ for 2 days, $20 \mu \mathrm{L}$ of suspension of $B$. cinerea $\left(10^{5}\right.$ spores $\mathrm{mL}^{-1}$ suspended in sterile distilled water) was placed $6 \mathrm{~cm}$ away from the plug of $20 \mu \mathrm{L}$ U. atrum $\left(10^{6}\right.$ spores $\mathrm{mL}^{-1}$ suspended in sterile distilled water) in the same Petri dish. PDA dishes inoculated with $U$. atrum or $B$. cinerea alone were used as controls. The dishes were incubated at $20{ }^{\circ} \mathrm{C}$ for 3 days and examined for the formation of inhibition zones between $U$. atrum or B. cinerea. A thin layer of PDA containing the pathogen sampled from the limit between $B$. cinerea and $U$. atrum was removed aseptically and used to study changes in structure of $B$. cinerea. The mycelium was then placed in a drop of sterile water on a glass slide. A coverslip was placed on the film, and the slide was observed under the microscope. The test was repeated twice each with 10 replicates (dishes).

\subsection{Plant Inoculation}

Detached leaves from six-week-old in vitro plantlets of grapevine (Vitis vinifera L. cv. Chardonnay) were treated with $30 \mu \mathrm{L}$ of water or $U$. atrum isolates $\left(10^{6}\right.$ spores $\left.\mathrm{mL}^{-1}\right)$, deposited on the top of each leaf. Three days later treatment, leaves were inoculated with $20 \mu \mathrm{L}$ of actively growing mycelium of B. cinerea $\left(10^{5}\right.$ spores $\mathrm{mL}^{-1}$ suspended in sterile distilled water) on the leaves surface. Control plants were treated similarly but with sterile distilled water. Ten plants were used for each treatment and the experiment was repeated twice. Observation of gray mold lesions were made 3 days after inoculation with $B$. cinerea, and samples were processed for light microscope investigations and electrolytes leakage, or weighed then immerged in nitrogen liquid and stored at $-80{ }^{\circ} \mathrm{C}$.

\subsection{Electrolytes Leakage Assessment}

Leaves were removed from the stem, rinsed several times with distilled water, and dried on filter paper. The leaves $(n=24)$ were incubated in $30 \mathrm{~mL}$ mannitol $(0.4 \mathrm{M})$ in $50 \mathrm{~mL}$ Erlenmeyer's at $24{ }^{\circ} \mathrm{C}$. After $20 \mathrm{~h}$ on a rotary shaker $(80 \mathrm{rpm})$, the conductance of the incubation medium was measured using a conductivity meter (Orion, Model 150) to determine electrolytes leakage. Tissue integrity was later destroyed by freezing at $-80{ }^{\circ} \mathrm{C}$. After thawing to room temperature, the conductivity of the bathing 
medium was measured to determine the total electrolytes content of the tissue. The degree of electrolytes leakage was calculated as described earlier [34].

\subsection{Tissue Processing for Light Microscope Study}

Section of leaves $\left(2 \mathrm{~mm}^{3}\right)$ were sampled from the sites of fungal entry of treated leaves and immediately transferred into $2 \%(\mathrm{w} / \mathrm{v})$ glutaraldehyde in $0.1 \mathrm{M}$ phosphate buffer $(\mathrm{pH} 7.24)$ with $1 \%(\mathrm{w} / \mathrm{v})$ sucrose and $1 \%(\mathrm{v} / \mathrm{v})$ tween 20 [34]. Each sample was rinsed 3 times for $5 \mathrm{~min}$ in $0.1 \mathrm{M}$ phosphate buffer ( $\mathrm{pH} 7.24)$ with $1 \%(\mathrm{w} / \mathrm{v})$ sucrose. The samples were post-fixed for $4 \mathrm{~h}$ in $1 \%(\mathrm{w} / \mathrm{v})$ osmium tetroxide in $0.1 \mathrm{M}$ phosphate buffer $(\mathrm{pH} 7.24)$ with $1 \%(\mathrm{w} / \mathrm{v})$ sucrose. Specimen were then dehydrated in alcohol series and embedded in araldite. Semi-thin sections $(2 \mu \mathrm{m})$ were cut with a glass knife on a Reichert U2 ultratome, and stained with the topographic reagent Toluidine blue [34].

\subsection{Protein Extraction and Chitinase Activity Assay}

Ten leaves per treatment were collected 4 days after plant inoculation (part 3.4) for chitinase extraction. Proteins were extracted by homogenizing ground frozen collected leaves [200 $\mathrm{mg}$ fresh weight (FW)] at $4{ }^{\circ} \mathrm{C}$ in $1 \mathrm{~mL}$ of $50 \mathrm{mM}$ sodium acetate buffer $(\mathrm{pH} 5)$, containing $0.25 \%$ of Triton $\mathrm{X} 100(\mathrm{v} / \mathrm{v})$. The homogenate was centrifuged at $3000 \times \mathrm{g}$ for $10 \mathrm{~min}$, and the supernatant was used to determine chitinase activity. The chitinase activity (E.C. 3.2.1.14) was based on the release of acid-soluble fragments from the substrate carboxymethyl-chitin-Remazol-Brilliant-Violet 5R according to the procedure described by Wirth and Wolf [35]. Each assay was performed in a $0.5 \mathrm{~mL}$ microfuge tube containing $200 \mu \mathrm{L}$ of CM-chitin-RBV, $150 \mu \mathrm{L}$ of sodium acetate buffer $(500 \mathrm{mM}$, $\mathrm{pH}$ 5.0), and $50 \mu \mathrm{L}$ crude enzyme. Solution was incubated at $37{ }^{\circ} \mathrm{C}$ for one minute; reaction was terminated by adding $500 \mu \mathrm{L}$ of cold $\mathrm{HCl}(0.3 \mathrm{~N})$, and then placed on ice for $10 \mathrm{~min}$. After centrifugation ( $3000 \times g$ for 10 min at $4{ }^{\circ} \mathrm{C}$ ), the supernatant was transferred to a microcuvette and $A_{550}$ was measured spectrophotometrically against a blank. Chitin content was calculated from a standard curve prepared in a similar way with a known amount of chitin. Measurements were conducted in triplicate. Results are expressed as the amount of chitin hydrolyzed per min per $\mathrm{g}$ of fresh weight.

\subsection{In Vitro Colonization with Isolates of $\mathrm{U}$. atrum}

Approximately 1-cm-long nodal explants, taken from 6-week-old plantlets with removed leaves, were dipped in the fungal antagonist inoculum $\left(10^{6}\right.$ spores $\left.\mathrm{mL}^{-1}\right)$, for $1 \mathrm{~min}$, blotted with sterile filter paper, and propagated on Martin et al. [36] medium as above. Non-inoculated controls were dipped only in phosphate buffer saline (PBS). The plants were grown in the growth chamber as above.

\subsection{Statistical Analyses}

Each experiment was repeated at least three times, with twenty-four plants evaluated per treatment, unless indicated otherwise. Antifungal activity test was done using ten petri dishes for each treatment. For chitinase activity, the results are expressed as the mean of two separate experiments (in each experiment three different extractions were pooled). For other experiments, results were analyzed statistically by subjecting data to ANOVA. Means for each treatment were separated with a least 
significant difference (LSD, $p<0.05$ ) multiple comparison test (Fisher's protected). Bars or means with the same letters represent values that are not significantly different according to Fisher's protected LSD test $(p<0.05)$.

\section{Conclusions}

The demonstration that pathogen growth was halted or even restricted and that biochemical compounds were elaborated in plant tissues treated with antagonists suggests that a biological elicitor may play a key role in the control of a large number of plant diseases. In recent years, the process of "plant immunization" or induced resistance has been the focus of considerable interest and has been abundantly documented [15]. The same process can be hypothesized when plants are treated with U. atrum.

In conclusion, both $U$. atrum isolates (U13 and U16) were effective in controlling Botrytis in vitro by the involvement of diverse mechanisms. Competition for nutrients and space have been reported to be the principal modes of action excluding the competitors without any antagonistic action like parasitism or antibiosis [9]. However, herein we noted that the antagonists halted the growth of the pathogen by inducing plant defenses and in same case (U13) by stimulating the growth of grapevine plantlets. Consequently, this study brings new modes of action of $A$. atrum. The next step should be the application of $U$. atrum U13 and U16 in field experiments. This should be a key step before concluding whether or not $U$. atrum can prevent the spread of $B$. cinerea infection in vineyards under our conditions. For use in integrated crop protection systems, a biocontrol agent must be compatible with chemical control agents. Schoene et al. [7] reported that $U$. atrum is insensitive to most pesticides used in grapevine meaning that an integration of this antagonist into crop protection measures is feasible in the vineyard, and it enables a Botrytis-control with U. atrum combined with chemical crop protection programs.

\section{Conflicts of Interest}

The authors declare no conflict of interest.

\section{References}

1. Kretschmer, M.; Leroch, M.; Mosbach, A.; Walker, A.S.; Fillinger, S.; Mernke, D.; Schoonbeek, H.J.; Pradier, J.M.; Leroux, P.; de Waard, M.A.; et al. Fungicide-driven evolution and molecular basis of multidrug resistance in field populations of the grey mould fungus Botrytis cinerea. PLoS Pathog. 2009, 5, e1000696.

2. Saladin, G.; Magné, C.; Clément, C. Stress responses of Vitis vinifera L. to the fungicides fludioxonil and pyrimethanil. Pestic. Biochem. Phys. 2003, 77, 125-137.

3. Compant, S.; Duffy, B.; Nowak, J.; Clément, C.; Ait Barka, E. Use of plant growth-promoting bacteria for biocontrol of plant diseases: Principles, mechanisms of action, and future prospects. Appl. Environ. Microbiol. 2005, 71, 4951-4959.

4. Yohalem, D.; Nielsen, K.; Green, H.; Funck Jensen, D. Biocontrol agents efficiently inhibit sporulation of Botrytis aclada on necrotic leaf tips but spread to adjacent living tissue is not prevented. FEMS Microbiol. Ecol. 2004, 47, 297-303. 
5. Köhl, J. Biocontrol of Foliar Diseases in Horticulture: Screening and Application of Ulocladium atrum for Grey Mould Control. In Implementation of Biocontrol in Practice in Temperate Regions-Present and Near Future, Proceedings of the International Workshop at Research Centre Flakkebjerg, Flakkebjerg, Denmark, 1-3 November 2005; Hansen, L., Ed.; Volume 119, pp. 211-218.

6. Jacometti, M.A.; Wratten, S.D.; Walter, M. Alternatives to synthetic fungicides for Botrytis cinerea management in vineyards. Aust. J. Grape Wine Res. 2010, 16, 154-172.

7. Schoene, P.; Oerke, E.C.; Dehne, H.W. A New Concept for Integrated Control of Gray Mold (Botrytis cinerea) in Grapevine. In Proceedings of British Crop Protection Conference-Pests and Diseases, The Brighton Hilton Metropole Hotel, Brighton, UK, 13-16 November 2000; pp. 1031-1036.

8. Roudet, J.; Dubos, B. Evaluation of a Three Year Study of Ulocladium atrum (strain 385) Control Agent of Vine Grey Rot in the Bordeaux Region. In Proceedings of the XIIth International Botrytis symposium, Reims, France, 3-7 July 2000.

9. Kohl, J.; Belanger, R.R.; Fokkema, N.J. Interaction of four antagonistic fungi with Botrytis aclada in dead onion leaves: A comparative microscopic and ultrastructural study. Phytopathology 1997, $87,634-642$.

10. Köhl, J.; van der Plas, C.H.; Molhoek, W.M.L.; Fokkema, N.J. Effect of interrupted leaf wetness periods on suppression of sporulation of Botrytis allii and B. cinerea by antagonists on dead onion leaves. Eur. J. Plant Pathol. 1995, 101, 627-637.

11. Köhl, J.; Molhoek, W.M.L.; Goosen-van der Geijn, H.; Lombaers-van der Plas, C. Potential of Ulocladium atrum for biocontrol of leaf spot through suppression of sporulation of Botrytis spp. BioControl 2003, 48, 349-359.

12. Szandala, E.S.; Backhouse, D. Effect of sporulation of Botrytiscinerea by antagonists applied after infection. Australas. Plant Pathol. 2001, 30, 165-170.

13. Kessel, G.J. Biological Control of Botrytis spp. by Ulocladium atrum: An Ecological Analysis; Landbouwuniversiteit Wageningen (Wageningen Agricultural University): Wageningen, the Netherlands, 1999.

14. Sriram, S.; Raguchander, T.; Babu, S.; Nandakumar, R.; Shanmugam, V.; Vidhyasekaran, P.; Balasubramanian, P.; Samiyappan, R. Inactivation of phytotoxin produced by the rice sheath blight pathogen Rhizoctonia solani. Can. J. Microbiol. 2000, 46, 520-524.

15. Benhamou, N.; Nicole, M. Cell biology of plant immunization against microbial infection: The potential of induced resistance in controlling plant diseases. Plant Physiol. Biochem. 1999, 37, $703-719$.

16. Hammerschmidt, R. Induced disease resistance, How do induced plants stop pathogens? Physiol. Mol. Plant Pathol. 1999, 55, 77-84.

17. Van Loon, L.C.; Bakker, P.A.H.M. Signalling in Rhizobacteria-Plant Interactions. In Ecological Studies. Root Ecology; De Kroon, J., Visser, E.J.W., Eds.; Springer Verlag: Berlin, Gremany, 2004; Volume 168, pp. 287-330.

18. Shibuya, N.; Minami, E. Oligosaccharide signalling for defence responses in plant. Physiol. Mol. Plant Pathol. 2001, 59, 223-233. 
19. Derckel, J.P.; Baillieul, F.; Manteau, S.; Audran, J.C.; Haye, B.; Lambert, B.; Legendre, L. Differential induction of grapevine defenses by two strains of Botrytis cinerea. Phytopathology 1999, 89, 197-203.

20. Bézier, A.; Lambert, B.; Baillieul, F. Study of defense-related gene expression in grapevine leaves and berries infected with Botrytis cinerea. Eur. J. Plant Pathol. 2002, 108, 111-120.

21. Punja, Z.K.; Zhang, Y.Y. Plant chitinases and their roles in resistance to fungal diseases. J. Nematol. 1993, 25, 526-540.

22. Dalisay, R.; Kuć, J. Persistence of reduced penetration by Colletotrichum lagenarium into cucumber leaves with induced systemic resistance and its relation to enhanced peroxidase and chitinase activities. Physiol. Mol. Plant Pathol. 1995, 47, 329-338.

23. Castoria, R.; de Curtis, F.; Lima, G.; Caputo, L.; Pacifico, S.; de Cicco, V. Aureobasidium pullulans (LS-30) an antagonist of postharvest pathogens of fruits: study on its modes of action. Postharvest Biol. Technol. 2001, 22, 7-17.

24. Renault, A.S.; Deloire, A.; Letinois, I.; Kraeva, E.; Tesniere, C.; Ageorges, A.; Redon, C.; Bierne, J. $\beta$-1,3-glucanase gene expression in grapevine leaves as a response to infection with Botrytis cinerea. Am. J. Enol. Vitic. 2000, 51, 81-87.

25. Berto, P.; Jijakli, M.H.; Lepoivre, P. Possible role of colonization and cell wall-degrading enzymes in the differential ability of three Ulocladium atrum strains to control Botrytis cinerea on necrotic strawberry leaves. Phytopathology 2001, 91, 1030-1036.

26. Hyakumachi, M. Plant-growth-promoting fungi from turfgrass rhizosphere with potential for disease suppression. Soil Microorg. 1994, 44, 53-68.

27. Kleifeld, O.; Chet, I. Trichoderma harzianum-interaction with plants and effect on growth response. Plant Soil 1992, 144, 267-272.

28. Blanchard, L.M.; Björkman, T. The role of auxin in enhanced root growth of Trichoderma-colonized sweet corn. HortScience 1996, 31, 688.

29. Harman, G.E.; Howell, C.R.; Viterbo, A.; Chet, I.; Lorito, M. Trichoderma species opportunistic avirulent plant simbionts. Nat. Rev. Microbiol. 2004, 2, 43-56.

30. Benítez, T.; Rincón, A.M.; Limón, M.C.; Codón, A.C. Biocontrol mechanisms of Trichoderma strains. Int. Microbiol. 2004, 7, 249-260.

31. Mejia, L.; Rojas, E.; Maynard, Z.; Bael, S.; Arnold, A.; Hebbar, P.; Samuels, G.; Robbins, N.; Herre, E. Endophytic fungi as biocontrol agents of Theobroma cacao pathogens. Biol. Control 2008, 46, 4-14.

32. Lee, K.; Pan, J.; May, G. Endophytic Fusarium verticillioides reduces disease severity caused by Ustilago maydis on maize. FEMS Microbiol. Lett. 2009, 299, 31-37.

33. Raghavendra, A.; Newcombe, G. The contribution of foliar endophytes to quantitative resistance to Melampsora rust. New Phytol. 2013, 197, 909-918.

34. Ait Barka, E.; Nowak, J.; Clement, C. Enhancement of chilling resistance of inoculated grapevine plantlets with a plant growth-promoting rhizobacterium, Burkholderia phytofirmans strain PsJN. Appl. Environ. Microbiol. 2006, 72, 7246-7252.

35. Wirth, S.J.; Wolf, G.A. Microplate colorimetric assay for endo-acting cellulase, xylanase, chitinase, $\beta-1,3$ glucanase and amylase extracted from forest soil horizons. Soil Biol. Biochem. 1992, 24, $511-519$. 
36. Martin, C.; Vernoy, R.; Carr, M.; Vesselle, G.; Collas, A.; Bougerey, C. The vine and techniques of in vitro cultivation. Bull. Org. Int. Vigne. 1987, 675-676, 447-458.

(C) 2013 by the authors; licensee MDPI, Basel, Switzerland. This article is an open access article distributed under the terms and conditions of the Creative Commons Attribution license (http://creativecommons.org/licenses/by/3.0/). 